\title{
Environmental Perpetuity Cost and Earning Yields of Oil and Gas Marketing Firms: Nigeria's experience
}

\author{
Nwafor, Chidi Benson ${ }^{a}$, Asuquo, Akabom Ita ${ }^{b}$, Inyang, Inyang Ochi ${ }^{c} \&$ Inyang, Ethel Ohanya ${ }^{d}$ \\ ${ }^{\text {a}}$ Ph.D. Student, Department of Accounting, Faculty of Management Sciences, University of \\ Calabar, Nigeria \\ ${ }^{b}$ Associate Professor, Department of Accounting, Faculty of Management Sciences, University of \\ Calabar, Nigeria \\ ${ }^{c}$ Lecturer, Department of Accounting, Faculty of Management Sciences, University of Calabar, \\ Nigeria \\ ${ }^{\mathrm{d}}$ Lecturer, Department of Accounting, Faculty of Management Sciences, University of Calabar, \\ Nigeria
}

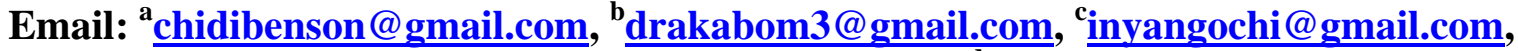 ethelinyang@gmail.com ${ }^{\mathrm{d}}$}

\begin{abstract}
The study examined the environmental perpetuity cost and earning yields of oil and gas marketing firms: Nigeria's experience. Its main objective was: to specifically examine the extent to which environmental perpetuity costs influence earning yields of oil and gas marketing firms taking evidence from Nigeria. To achieve the objective, an ex-post facto design was employed and relevant data were obtained from secondary source. Multiple regression analytical tool was used to analyse the data in order to verify the hypotheses formulated for the study. The findings indicated that donations as a perpetuity cost positively influences earning yield though the influence is not a very strong one; support/social cost to destitute and less privileged significantly affect earnings per share; support to motherless babies' homes and others significantly affect earnings per share; and donations/ social cost to nongovernmental organization significantly affect earnings per share. The researchers then recommended that government should encourage listed firms to disclose their donations which will strengthen the earning per share of these firms via increased employee productivity.
\end{abstract}

Keywords: Cost, Earning, Environmental, Firms, Marketing, Perpetuity, Yields,

\section{Introduction}

The Nigerian economy is anchored on the revenue accruing from oil exploration through continuous inflow of oil and gas. The host people who live in the shadow of their environment embrace the pattern of accounting for perpetuity and it sustainable growth. Crowther (2000), posit that it is a method of interaction within the society. Blowfield and Murray (2008) viewed sustainability as a way of improving on the high quality of life which involves organization to restructure their performance which is built on environmental perspective (Helg, 2007). Sustainable development encapsulates various areas of life, it involves absolute respect of the operators. In this process, government provides the needed quality and infrastructural facilities. The aim of every business is to acquire successful objectives on how social disclosure produces effective reputation by improving on the market share. Social cost as a way of increasing cost of production and could lead to a decline in outcome. On the other hand, social costs produce negative effect on performance. However, costs with benefits improve the qualitative aspect of the communities as well as the entire society. The study therefore is to determine how donations made to disabled persons, less privilege and non- governmental organizations significantly affect earnings per share;

\section{Literature review}

The study adopted corporate social performance. It shows that prices are not comprehensively reflected on consumption of a product or service. The theory is embedded on manufacturers and those who consume by not 
bearing the costs of the economic activity. It depicts that number of those who have the capability to improve the aggregate utility and how it could be beneficial. Also, when there is conflict, it could lead to problems that will involve other groups as well as influencing the policy. Bowen (1953) opined that social responsibility of businessmen is voluntarily for them to follow the policies which are preferable as values of the society (Mele, 2014). LanMitroff (1983) view corporations as an entity is obligated to carry out group responsibility. These postulations capture group of persons who are part of the business such as employees, shareholders etc.

\subsection{Conceptual framework}

Agriculture is a catalyst of economic growth in Nigeria. The effect of its operations has brought devastations on many areas where the oil resources are extracted. Social Cost Accounting in Nigeria has a negative impact on the oil industry. Community that produces oil requires environmental protection in order to affect the host communities. Nigeria today is suffering from poor infrastructural development especially in the area of road construction and this lead to unassailable transportation networks. Coker (2008) confirmed most companies are hostile as a result of sourcing energy. The scholar is in tandem that the practice of social accounting is shaped by social-economic factor. Social cost is aimed on socio-economic development such as health care provision etc. The existence of social cost has accrued because of continuous growth that made most of the organizations to inject more funds socially. The purpose of this concept is proffered in assisting the society to provide various facilities and how it could be record, analyzed, interpreted and reported proficiently and professionally. The reporting of non-financial information has narrative disclosure which is accorded statistically with much social reporting and the process of comparing with other companies makes it cumbersome. Due to a positive bias, most companies report the available vital information in social reports when there is no legislations binding social cost reporting.

\subsection{Accounting for environmental perpetuity cost}

Daly and Cobb (1989) agree that social accounting conflicts in arises when the community and organization, it is largely with a normative concept that enlarges the scope of accounting: It is comprised of honor stakeholders' information right balance corporate strengths with corporate social responsibility etc. Social accounting is meant to facilitate the achievement of the organizational objectives. It is focused with substantial selfreporting, individual reports and organizations, for example; it increases information for decision-making, products are genuine and there is availability of market development. It is concerned with how costs are structured in an organization. Therefore, inflow of message is communicated with the natural environment. It embraces personal reporting through companies, etc. Daly and Cobb (1989), Asuquo, Dan, Odey, Linus, Uklala, and Tapang (2021); Effiong and Asuquo (2010) assessed environmental accounting on sustainable economic welfare. It depicts that financial issues rises when there is environmental legislation. Also inputs, outputs of the organization are centred on great success when there is an environmental impact. Social accounting is independently audited and sustainability accounts are vitally produced. According to Global Reporting Initiative, fair trade organizations are known first in publishing audited accounts in public limited company. It is generally known that Canadian Institute of Chartered Accountants featured on returns or benefits. In this case, if there is no gain, compensations are done to those persons that are affected. Social accountings are not captured in accounting statement rather based on how to create value toward increasing financial performance.

\subsection{Empirical studies}

Griffin and Mahon (1997) investigated corporate social performance and financial performance. The study adopted secondary source of data using panel data analysis. The study discovered that corporate social performance is positively related with Return on asset. The study concluded that corporate social affected performance. Balmer and Greyser (2006) conducted corporate social responsibility on firm performance. It was found that corporate social responsibility affected firms' profit. Tinker and Gray (2003) examined social disclosures in the market place. Hazilla and Kopp (1990) posited that accounting raises cost of production. Monk, Richmond and Quarter (2003) propounded that cost is measured in terms of quality. Corson (2002), Asuquo (2012), Asuquo, Dan, and Effiong, (2020) simplified on how profits are maximized when there the volume increases and consideration is given to environmental sustainability.

\section{Methodology 3.1Research design}


Ex-post facto design and secondary sources were employed using annual reports of the Nigerian Securities and Exchange Commission. Ordinary least square of multiple regression technique was used. F-statistics determines the overall significance of the test variables. Ordinary least square was used to see the effect of independent variables on dependent variable, as expressed thus:

\subsection{Model specification}

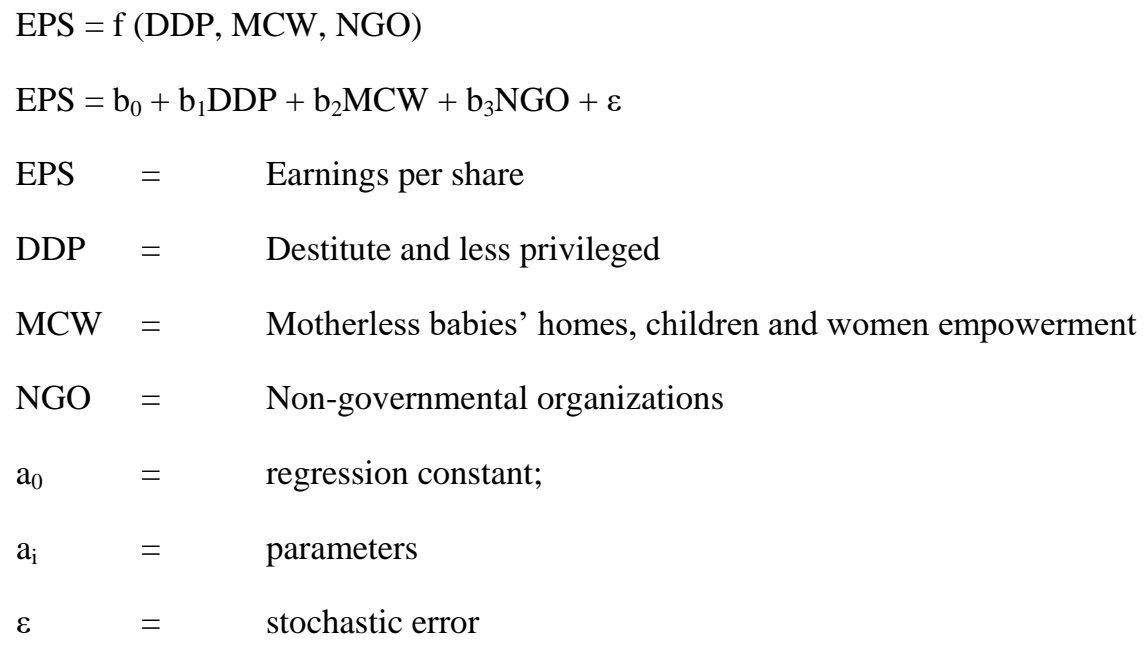

\section{Presentation of data}

The presentation of data on EPS, DDP, MCW, NGO extracted from the annual reports of MOBIL, FORTE OIL, CONOI, OANDO

Table 4.1. Mobil environmental perpetuity costs

\begin{tabular}{|c|c|c|c|c|}
\hline YEAR & 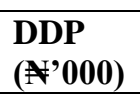 & 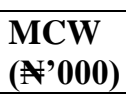 & $\begin{array}{l}\text { NGO } \\
\text { (\$'000) }\end{array}$ & $\begin{array}{l}\begin{array}{l}\text { EPS } \\
\left({ }^{\prime} 000\right)\end{array} \\
\end{array}$ \\
\hline 1 & 600 & 3000 & 2000 & 3.45 \\
\hline 2 & 460 & 2100 & 2700 & 2.46 \\
\hline 3 & 500 & 3000 & 1800 & 6.06 \\
\hline 4 & 280 & 1000 & 3000 & 7.32 \\
\hline 5 & 350 & 2000 & 1100 & 10.08 \\
\hline 6 & 400 & 382 & 2184 & 7.14 \\
\hline 7 & 395 & 980 & 3400 & 8.54 \\
\hline 8 & 280 & 2700 & 2000 & 9.76 \\
\hline 9 & 620 & 3000 & 2700 & 9.46 \\
\hline 10 & 500 & 1800 & 3000 & 12.93 \\
\hline 11 & 400 & 1000 & 2400 & 12.14 \\
\hline 12 & 250 & 980 & 3200 & 8.56 \\
\hline 13 & 300 & 750 & 3000 & 9.65 \\
\hline 14 & 2500 & 1000 & 2100 & 17.73 \\
\hline 15 & 3500 & 2000 & 4000 & 13.51 \\
\hline
\end{tabular}

Source: Annual reports of Mobil extracted by Authors, 2021

Table 4.2. Total environmental perpetuity costs

\begin{tabular}{lllll}
\hline YEAR & $\begin{array}{l}\text { DDP } \\
\text { (\$'000) }\end{array}$ & $\begin{array}{l}\text { MCW } \\
\text { (\$'000) }\end{array}$ & $\begin{array}{l}\text { NGO } \\
\text { (\$000) }\end{array}$ & $\begin{array}{l}\text { EPS } \\
\text { (\$'000) }\end{array}$ \\
\hline 1 & 1300 & 600 & 900 & 7.40 \\
2 & 1100 & 900 & 1200 & 8.23 \\
3 & 1200 & 500 & 1000 & 9.04
\end{tabular}




\begin{tabular}{lllll}
4 & 1000 & 700 & 1500 & 8.18 \\
5 & 600 & 800 & 1000 & 10.65 \\
6 & 1000 & 800 & 1100 & 7.41 \\
7 & 1100 & 2300 & 200 & 9.59 \\
8 & 1200 & 1100 & 700 & 12.94 \\
9 & 1400 & 1800 & 1000 & 11.69 \\
10 & 1200 & 1400 & 200 & 16.01 \\
11 & 800 & 2400 & 600 & 11.23 \\
12 & 800 & 2200 & 1000 & 13.76 \\
13 & 12941 & 3700 & 400 & 15.71 \\
14 & 44897 & 200 & 1000 & 13.03 \\
15 & 33259 & 600 & 150 & 11.92 \\
\hline
\end{tabular}

Source: Annual reports of Total Company by Authors, 2021

Table 4.3. MRS environmental perpetuity costs

\begin{tabular}{lllll}
\hline YEAR & $\begin{array}{l}\text { DDP } \\
\text { (\$'000) }\end{array}$ & $\begin{array}{l}\text { MCW } \\
\text { (\$'000) }\end{array}$ & $\begin{array}{l}\text { NGO } \\
\text { (\$'000) }\end{array}$ & $\begin{array}{l}\text { EPS } \\
\text { (\$'000) }\end{array}$ \\
\hline 1 & 340 & 780 & 500 & 7.45 \\
2 & 200 & 560 & 400 & 7.21 \\
3 & 230 & 700 & 700 & 8.23 \\
4 & 480 & 780 & 900 & 6.21 \\
5 & 300 & 800 & 650 & 5.29 \\
6 & 250 & 650 & 800 & 6.56 \\
7 & 200 & 600 & 250 & 7.71 \\
8 & 300 & 800 & 400 & -4.71 \\
9 & 420 & 900 & 200 & 4.14 \\
10 & 350 & 700 & 300 & 7.27 \\
11 & 400 & 600 & 200 & 2.42 \\
12 & 300 & 1900 & 0 & 0.81 \\
13 & 200 & 2000 & 0 & 2.51 \\
14 & 900 & 1302 & 0 & 2.94 \\
15 & 350 & 2555 & 1367 & 3.68 \\
\hline
\end{tabular}

Source: Annual reports of MRS by Authors, 2021

Table 4.4. Forte Oil environmental perpetuity costs

\begin{tabular}{lllll}
\hline YEAR & $\begin{array}{l}\text { DDP } \\
\text { (\$000) }\end{array}$ & $\begin{array}{l}\text { MCW } \\
\text { (\$000) }\end{array}$ & $\begin{array}{l}\text { NGO } \\
\text { (\$'000) }\end{array}$ & $\begin{array}{l}\text { EPS } \\
\text { (\$'000) }\end{array}$ \\
\hline 1 & 2000 & 150 & 1500 & -14.60 \\
2 & 2030 & 50 & 2880 & 9.98 \\
3 & 1800 & 150 & 1500 & 2.83 \\
4 & 1600 & 100 & 2300 & 2.06 \\
5 & 1200 & 50 & 2500 & -4.52 \\
6 & 1500 & 150 & 1800 & -2.74 \\
7 & 1400 & 180 & 2500 & 7.26 \\
8 & 1500 & 200 & 3500 & 6.47 \\
9 & 1200 & 150 & 2800 & -8.48 \\
10 & 50 & 190 & 2770 & -2.54 \\
11 & 0 & 200 & 500 & -20.02 \\
12 & 100 & 150 & 100 & 0.61 \\
13 & 230 & 300 & 200 & 4.25 \\
14 & 400 & 700 & 1000 & 2.42 \\
15 & 750 & 730 & 1250 & 4.39 \\
\hline
\end{tabular}

Source: Annual reports of Forte Oil Company by Authors, 2021 
Table 4.5. Conoil environmental perpetuity costs

\begin{tabular}{lllll}
\hline YEAR & $\begin{array}{l}\text { DDP } \\
\text { (\$'000) }\end{array}$ & $\begin{array}{l}\text { MCW } \\
\text { (\$'000) }\end{array}$ & $\begin{array}{l}\text { NGO } \\
\text { (\$000) }\end{array}$ & $\begin{array}{l}\text { EPS } \\
\text { (\$000) }\end{array}$ \\
\hline 1 & 2300 & 1200 & 1400 & 6.54 \\
2 & 1700 & 2100 & 2500 & 4.42 \\
3 & 1200 & 3420 & 1780 & 1.45 \\
4 & 2200 & 3600 & 1200 & 3.37 \\
5 & 2400 & 3400 & 1600 & 4.23 \\
6 & 1700 & 2400 & 1800 & 4.05 \\
7 & 2300 & 3300 & 2500 & 3.72 \\
8 & 2700 & 2400 & 3600 & 2.62 \\
9 & 1100 & 1600 & 2900 & 3.33 \\
10 & 4900 & 1400 & 2300 & 4.02 \\
11 & 4500 & 3400 & 1300 & 4.32 \\
12 & 3600 & 2700 & 2300 & 1.03 \\
13 & 4200 & 3500 & 2600 & 4.62 \\
14 & 3400 & 1800 & 3500 & 1.20 \\
15 & 2700 & 3200 & 2800 & 3.33 \\
\hline
\end{tabular}

Source: Annual reports of Conoil Company by Authors, 2021

Table 4.6. Oando environmental perpetuity costs

\begin{tabular}{lllll}
\hline YEAR & $\begin{array}{l}\text { DDP } \\
\text { (\$'000) }\end{array}$ & $\begin{array}{l}\text { MCW } \\
\text { (\$'000) }\end{array}$ & $\begin{array}{l}\text { NGO } \\
\text { (\$'000) }\end{array}$ & $\begin{array}{l}\text { EPS } \\
\text { (\$'000) }\end{array}$ \\
\hline 1 & 12000 & 1324 & 1325 & 5.34 \\
2 & 13254 & 1236 & 899 & 5.89 \\
3 & 10000 & 1400 & 1000 & 6.10 \\
4 & 11200 & 1500 & 700 & 6.34 \\
5 & 13232 & 2345 & 700 & 6.65 \\
6 & 26103 & 3116 & 400 & 7.45 \\
7 & 23572 & 4605 & 138 & 7.51 \\
8 & 8899 & 5702 & 500 & 9.22 \\
9 & 25865 & 2056 & 2163 & 11.32 \\
10 & 13281 & 53614 & 1011 & 11.32 \\
11 & 168709 & 3947 & 76865 & 8.29 \\
12 & 43963 & 70619 & 12306 & 12.60 \\
13 & 28707 & 61700 & 7215 & 22.72 \\
14 & 14162 & 58230 & 1729 & -20.76 \\
15 & 30908 & 32035 & 4104 & 15.78 \\
\hline
\end{tabular}

Source: Annual reports of Oando Company

Table 4.7. Environmental perpetuity costs

\begin{tabular}{lllll}
\hline YEAR & $\begin{array}{l}\text { DDP } \\
\text { (\$'000) }\end{array}$ & $\begin{array}{c}\text { MCW } \\
\text { (\$千000) }\end{array}$ & $\begin{array}{l}\text { NGO } \\
\text { (\$000) }\end{array}$ & $\begin{array}{l}\text { EPS } \\
\text { (\$'000) }\end{array}$ \\
\hline 1 & 18540 & 7054 & 7625 & 15.58 \\
2 & 18744 & 6946 & 10579 & 38.19 \\
3 & 14930 & 9170 & 7780 & 33.71 \\
4 & 16760 & 7680 & 9600 & 33.48 \\
5 & 18082 & 9395 & 7550 & 32.38 \\
6 & 30953 & 7498 & 8084 & 29.87 \\
7 & 28967 & 11965 & 8988 & 44.33 \\
8 & 14879 & 12902 & 10700 & 36.30 \\
9 & 30605 & 9506 & 11763 & 31.46
\end{tabular}




\begin{tabular}{lllll}
10 & 20281 & 59104 & 9581 & 49.01 \\
11 & 174809 & 11547 & 81865 & 18.38 \\
12 & 49013 & 78549 & 18906 & 37.37 \\
13 & 46578 & 71950 & 13415 & 59.46 \\
14 & 66259 & 63232 & 9329 & 16.56 \\
15 & 71467 & 41120 & 13671 & 52.61 \\
\hline
\end{tabular}

Source: Researcher's compilations, 2021.

Table 4.8. Logarithm of environmental perpetuity costs

\begin{tabular}{lllll}
\hline YEAR & $\begin{array}{l}\text { LOG } \\
\text { (DDP) }\end{array}$ & $\begin{array}{l}\text { LOG } \\
(\mathbf{M C W})\end{array}$ & $\begin{array}{l}\text { LOG } \\
\text { (NGO) }\end{array}$ & $\begin{array}{l}\text { LOG } \\
(\mathbf{E P S})\end{array}$ \\
\hline 1 & 4.26811 & 3.848435 & 3.88224 & 1.192567 \\
2 & 4.272862 & 3.841735 & 4.024445 & 1.58195 \\
3 & 4.17406 & 3.962369 & 3.89098 & 1.527759 \\
4 & 4.224274 & 3.885361 & 3.982271 & 1.524785 \\
5 & 4.257246 & 3.972897 & 3.877947 & 1.510277 \\
6 & 4.490703 & 3.874945 & 3.907626 & 1.475235 \\
7 & 4.461904 & 4.077913 & 3.953663 & 1.646698 \\
8 & 4.172574 & 4.110657 & 4.029384 & 1.559907 \\
9 & 4.485792 & 3.977998 & 4.070518 & 1.497759 \\
10 & 4.307089 & 4.771617 & 3.981411 & 1.690285 \\
11 & 5.242564 & 4.062469 & 4.913098 & 1.264346 \\
12 & 4.690311 & 4.895141 & 4.2766 & 1.572523 \\
13 & 4.668181 & 4.857031 & 4.127591 & 1.774225 \\
14 & 4.821245 & 4.800937 & 3.969835 & 1.21906 \\
15 & 4.854106 & 4.614053 & 4.1358 & 1.721068 \\
\hline
\end{tabular}

Source: Researcher's compilations, 2021 
Table 4.9. Regression results

Dependent variable: EPS

\begin{tabular}{|c|c|c|c|c|}
\hline Variable & $\begin{array}{l}\text { Estimated } \\
\text { Coefficients }\end{array}$ & $\begin{array}{l}\text { Standard } \\
\text { error }\end{array}$ & $\begin{array}{l}\mathrm{T}- \\
\text { statistics }\end{array}$ & P-value \\
\hline Constant & 1.477 & 0.783 & 2.885 & 0.00 \\
\hline DDP & 0.00 & 0.533 & 2.147 & 0.035 \\
\hline MCW & 3.242 & 0.127 & 2.897 & 0.084 \\
\hline NGO & 0.161 & 0.301 & 2.536 & 0.013 \\
\hline$R=0.527$ & & & & \\
\hline$R^{2}=0.378$ & & & & \\
\hline Adjusted $\mathrm{R}^{2}=0.281$ & & & & \\
\hline $\mathrm{SEE}=0.16681$ & & & & \\
\hline F-statistics $=3.813$ & & & & \\
\hline $\mathrm{Sig}=0.001$ & & & & \\
\hline $\begin{array}{l}\text { Durbin Watson }=2.506 \\
\text { df } 1=3 \text { df } 2=11\end{array}$ & & & & \\
\hline
\end{tabular}

Researcher's estimation, 2021

The coefficient of determination $\mathrm{R}^{2}$ of 0.378 implies that 37.8 per cent of the change in profit is accounted for change in explanatory while 62.2 per cent is unexplained. The $\mathrm{R}^{2}$ indicates that there is a positive relationship between criterion and predictors. The adjusted $\mathrm{R}^{2}$ of 0.281 or 28.1 per cent of EPS is affected by changes of the unexplained value as 71.9 per cent accounted by white noise. The DW statistics value of 2.506 depicted no degree of correlation. The F-statistic was statistically significant. F calculated was greater than the F tabulated.

\section{Findings}

The major findings of this study include:

1. Support/ social cost to destitute and less privileged significantly affect earnings per share

2. Support to motherless babies' homes and others significantly affect earnings per share

3. Donations/ social cost to non-governmental organization significantly affect earnings per share.

\subsection{Conclusion}

Environmental perpetuity cost positively affected the corporate performance. The incorporated factors significantly influenced the performance of earnings per share (EPS). Social cost disclosure was deterministic with a positive correlation with different performances which led to a long run outcome.

\subsection{Recommendations}

In line with the findings, the following recommendations were made:

i. Management of companies should give special treatment to cost accounting in order to stimulate their performance.

ii. Organizations should create a strategy that will improve business motive and also improvise the community in line with social amenities.

iii. Firms should have a developmental skill that will create the opportunity of sharing from the dividend. This will enhance the performance of the employees by increasing their productivity.

\section{References}

[1] Asuquo, A. I., Dan, N. O., Odey, I. O., Linus, M. U., Uklala, A. P., \&Tapang, A. T. (2021) Environmental operations review and stakeholders' wealth of extracting firms: Evidence from Nigeria. International Journal Financial Research, 12(3, Special issue):172-180.

[2] Asuquo, A. I., Dan, N. O., \& Effiong, G.T. (2020). Effect of eco-friendly costs on net revenue of cement producing firms. International Journal of Scientific and Technology Research, 9(9), 235-240.

[3] Asuquo, A. I. (2012). Environmental friendly policies and their financial effects on corporate performance of selected oil and gas companies in Niger Delta Region of Nigeria. American International Journal of Contemporary Research: Centre for Promoting Ideas, 2(1), 168-173. 
[4] Effiong, S. A., \& Asuquo, A. I. (2010). Environmental accounting and Environmental cost reporting: Implications and prospects for Business survival. African Journal of Management and Administration, 3 (4) $144-147$.

[5] Balmer, J. \& Greyser, L. (2006). Corporate social disclosure practice: A comparative international analysis. Advances in Public Interest Accounting, 3, 159 - 176.

[6] Blowfield, M., \& Murray, A. (2008). Corporate responsibility - A critical introduction. Oxford: University Press

[7] Bowen, H.R. (1953). Social responsibilities of the businessman. London: City university of London press.

[8] Coker, D. L. (2008).Corporate social responsibility in Nigeria. Owerri, Nigeria: Davisco Press Inc.

[9] ] Corson, M. (2002). Some determinants of social and environmental disclosures in New Zealand companies. Accounting, Auditing and Accountability Journal, 9 (1), 77-108.

[10] Crowther, D. (2000). Social and environmental accounting. London: Financial Times Prentice Hill.

[11] Daly, H. E. \& Cobb, J. (1989).For the common good: redirecting the economy toward community, the environment, and a sustainable future. New Jersey, United States: Beacon press.

[12] Griffin, J. J. \& Mahon, E. (1997). The corporate social performance and corporate financial performance debate: Twenty-five years of incomparable research. Business Sociology, 36, 5-31.

[13] Griffin J \& Mahon, J. (1997) Business and Society 1:73-75. The Relationship between Corporate Social Performance and Corporate Financial Performance in the Banking Sector. Maria-Gaia Soana - 2011 Journal of Business Ethics 104 (1):133-148.

[14] Hazilla, M. \& Kopp, R. (1990). Social cost of environmental quality regulations: A general equilibrium Analysis. Journal of Political Economy, 853-73.

[15] Helg, A. (2007). Corporate social responsibility from a Nigerian perspective.

[16] Mele, D. (2006). Corporate social responsibility theories: Mapping the territory. Journal of Business Ethics, $53,51-71$.

[17] Mitroff, I. (1983). Archetypal social systems analysis: On the deeper structure of human systems. Academy of Management Review, 8(3): 387397.

[18] Mook, L., Richmond, B. J. \& Quarter, J. (2003). Integrated social accounting for nonprofits: A case from Canada. Voluntas International Journal, 12(3), 110-119.

[19] Tinker, T., \& Gray, R. (2003). Beyond a critique of pure reason: from policy to politics to praxis in environmental and social research. Accounting, Auditing and Accountability Journal, 16(5): 727 - 761.

[20] Waddock, S.A. \&Graves, S.B. (1997). The Corporate Social Performance Financial Performance Link. Strategic Management Journal, 18, 303-319. 